\title{
The influence of the synoptic regime on stable water isotopes in precipitation at Dome $C$, East Antarctica
}

\author{
Elisabeth Schlosser ${ }^{1,2}$, Anna Dittmann ${ }^{1}$, Barbara Stenni $^{3}$, Jordan G. Powers ${ }^{4}$, Kevin W. Manning ${ }^{4}$, \\ Valérie Masson-Delmotte $^{5}$, Mauro Valt ${ }^{6}$, Anselmo Cagnati ${ }^{6}$, Paolo Grigioni ${ }^{7}$, and Claudio Scarchilli ${ }^{7}$ \\ ${ }^{1}$ Inst. of Atmospheric and Cryospheric Sciences, University of Innsbruck, Innsbruck, Austria \\ ${ }^{2}$ Austrian Polar Research Institute, Vienna, Austria \\ ${ }^{3}$ Department of Environmental Sciences, Informatics and Statistics, Ca 'Foscari University of Venice, Venice, Italy \\ ${ }^{4}$ National Center for Atmospheric Research, Boulder, CO, USA \\ ${ }^{5}$ Laboratoire des Sciences du Climate et de l'Environnement, Gif-sur-Yvette, France \\ ${ }^{6}$ ARPA Center of Avalanches, Arabba, Italy \\ ${ }^{7}$ Laboratory for Observations and Analyses of the Earth and Climate, ENEA, Rome, Italy
}

Correspondence to: Elisabeth Schlosser (elisabeth.schlosser@uibk.ac.at)

Received: 13 February 2017 - Discussion started: 24 February 2017

Revised: 30 August 2017 - Accepted: 8 September 2017 - Published: 20 October 2017

\begin{abstract}
The correct derivation of paleotemperatures from ice cores requires exact knowledge of all processes involved before and after the deposition of snow and the subsequent formation of ice. At the Antarctic deep ice core drilling site Dome $\mathrm{C}$, a unique data set of daily precipitation amount, type, and stable water isotope ratios is available that enables us to study in detail atmospheric processes that influence the stable water isotope ratio of precipitation. Meteorological data from both automatic weather station and a mesoscale atmospheric model were used to investigate how different atmospheric flow patterns determine the precipitation parameters. A classification of synoptic situations that cause precipitation at Dome $\mathrm{C}$ was established and, together with back-trajectory calculations, was utilized to estimate moisture source areas. With the resulting source area conditions (wind speed, sea surface temperature, and relative humidity) as input, the precipitation stable isotopic composition was modeled using the so-called Mixed Cloud Isotope Model (MCIM). The model generally underestimates the depletion of ${ }^{18} \mathrm{O}$ in precipitation, which was not improved by using condensation temperature rather than inversion temperature. Contrary to the assumption widely used in ice core studies, a more northern moisture source does not necessarily mean stronger isotopic fractionation. This is due to the fact that snowfall events at Dome $\mathrm{C}$ are often associated with warm air advection due to amplification of planetary waves, which
\end{abstract}

considerably increases the site temperature and thus reduces the temperature difference between source area and deposition site. In addition, no correlation was found between relative humidity at the moisture source and the deuterium excess in precipitation. The significant difference in the isotopic signal of hoarfrost and diamond dust was shown to disappear after removal of seasonality. This study confirms the results of an earlier study carried out at Dome Fuji with a shorter data set using the same methods.

\section{Introduction and previous work}

\subsection{Ice cores in paleoclimatology}

Ice cores from the vast ice sheets of Greenland and Antarctica have proven to be of high value in paleoclimate research. Of particular importance is the use of stable water isotope ratios as proxy for deriving past temperatures. However, it has been shown that the calibration of the "paleothermometer" is not as straightforward as originally assumed. Various factors apart from air temperature influence the stable isotope ratio, both before and after the deposition of the snow that develops into ice by metamorphosis. Postdepositional processes were thought to occur mainly within the snow pack, firn, or ice. Recent studies have shown, however, that the in- 
teraction between the uppermost layers of the snowpack and the overlying atmosphere between precipitation events also plays an important role. This was found in both Greenland (Steen-Larsen et al., 2013; Bonne et al., 2014) and Antarctica (Casado et al., 2016a, b; Ritter et al., 2016; Touzeau et al., 2016) as well as in laboratory experiments (Ebner et al., 2017).

In this study we focus on the processes before deposition, namely atmospheric processes related to moisture transport and precipitation formation. The precipitation data used here enable us to exclude postdepositional processes to study the purely atmospheric influence on precipitation. Since the stable water isotope ratio changes during evaporation and condensation processes (Dansgaard, 1964), it is important to know as much as possible about the history of the precipitation observed at an ice core drilling site, specifically moisture source, moisture transport paths, and meteorological conditions at both the moisture source and the deposition site. Precipitation measurements in Antarctica are rare due to the large technical difficulties of measuring precipitation at extremely low temperatures or high wind speeds. However, at the deep-drilling location Dome $\mathrm{C}$ on the East Antarctic plateau, a series of precipitation data has been collected that includes not only precipitation amounts but also precipitation type and stable isotope ratios. This unique data set can be combined with a full meteorological data set including radiosonde data, automatic weather station (AWS) data, and atmospheric model data. This, for the first time, allows us to study in detail the synoptic conditions that lead to precipitation at Dome $\mathrm{C}$ and how they are related to the precipitation stable isotope ratios. We compare our results to those of a similar study carried out by Dittmann et al. (2016) for Dome Fuji, Dronning Maud Land (DML), another deep ice core drilling site, where a 1-year series of combined stable isotope and precipitation data is available. In both studies exactly the same methods were used for calculation of transport pathways and isotopic fractionation as well as for synoptic analysis, which is highly valuable as often past studies have site-specific approaches, making comparisons very challenging.

\subsection{Stable isotopes}

Since the ground-breaking work of Dansgaard (1964), stable water isotopes have become one of the most important parameters measured in ice cores. An empirical linear relationship was found between the annual mean air temperature (derived from the $10 \mathrm{~m}$ snow temperature) and the annual mean $\delta^{18} \mathrm{O}$ of snow samples along traverses in Antarctica and Greenland (Jouzel et al., 1997). However, it became clear fairly early that this spatially derived relationship was different from the corresponding temporal relationship and thus could not be used as calibration for calculating paleotemperatures from ice core stable isotope ratios (e.g., Masson-Delmotte et al., 2008). More recently, it has been found that the temporal relationship is not constant for different climates or even time periods within a glacial or interglacial (Sime et al., 2009). Spatial differences in the temporal relationship are common, and the relationship can vary with season (e.g., Kuettel et al., 2012). While the empirical equation relates the stable isotope ratio only to the condensation temperature at the deposition site, various other factors influence this ratio, such as moisture source conditions and vertical and horizontal transport paths, entrainment of additional moisture along the way, sea ice conditions, seasonality and intermittency of precipitation, and postdepositional processes. The second-order parameter deuterium excess $\left(d=\delta \mathrm{D}-8 \times \delta^{18} \mathrm{O}\right)$, which combines the information from $\delta^{18} \mathrm{O}$ and deuterium, has been used to derive information about both condensation temperature and moisture source conditions, namely wind speed, sea surface temperature, and relative humidity (e.g., Stenni et al., 2001; Uemura et al., 2012). Most recently, due to the development of new measuring techniques, the rare isotope ${ }^{17} \mathrm{O}$ and the corresponding ${ }^{17} \mathrm{O}$ excess have been introduced into ice core studies (e.g., Landais et al., 2008, 2012; Schoenemann et al., 2014). The ${ }^{17} \mathrm{O}$ excess is supposed to be insensitive to evaporation temperature and less sensitive than $d$ excess to equilibrium fractionation processes during formation of precipitation. Thus it may offer the potential of disentangling the different effects of fractionation during evaporation, moisture transport, and precipitation formation (Schoenemann et al., 2014).

A variety of models is used to simulate isotopic fractionation, from simple Rayleigh-type distillation models to fully three-dimensional atmospheric circulation models. So far, most models are still based on the early theories developed by Jouzel and Merlivat (1984). Ciais and Jouzel (1994) extended this theory to mixed clouds in their Mixed Cloud Isotope Model (MCIM), which is described further in the methods section.

Kavanaugh and Cuffey (2003) developed a model of intermediate complexity (ICM), more complex than simple Rayleigh-type models but not as sophisticated as general circulation models (GCM), to study how variations in single climate parameters or in fundamental characteristics of isotopic distillation affect the stable isotope ratio of polar precipitation. Schoenemann and Steig (2016) applied their model to ${ }^{17} \mathrm{O}$ excess, using data from Vostok and the WAIS core for comparison. GCMs are so far not able to correctly represent $d$ excess or ${ }^{17} \mathrm{O}$ excess measured at Dome $\mathrm{C}$ (Stenni et al., 2010). In a most recent study, Steen-Larsen et al. (2017) evaluated various isotope enabled GCMs against in situ atmospheric water vapor isotope measurements. They found that, apart from a poor performance of all models for $d$ excess, biases in $\delta^{18} \mathrm{O}$ could not be explained simply by model biases in air temperature and humidity.

In the discussion of sea level rise, the possibility of a mitigation of sea level rise by increased Antarctic precipitation, the most important component of the surface mass balance, is 
often mentioned (e.g., Church et al., 2013). However, the relationship between stable isotope ratios and precipitation or accumulation is yet fully understood. Most commonly, the assumption of a positive correlation between stable isotope ratio (as proxy for air temperature) and accumulation rate has been used based on the relationship between temperature and saturation water vapor pressure (Clausius-Clapeyron). However, contrasting results are found in the recent literature. While Frieler et al. (2015), using both model and ice core data, state that Antarctic accumulation increases with rising air temperature, Fudge et al. (2016) found that the relationship between accumulation and temperature has not been constant over the past 30000 years in West Antarctica. They stated that atmospheric dynamics play a more important role than thermodynamics, which had also been found by Altnau et al. (2015) and Schlosser et al. (2014) in coastal DML.

\subsection{Synoptic analysis}

In the past, precipitation in the interior of the Antarctic continent was only poorly understood because only a few meteorological observatories have existed in continental Antarctica. A analysis of satellite imagery has brought only limited progress due to the difficulty of distinguishing between clouds and the snow surface (Massom et al., 2004). Since the improvement of global and mesoscale atmospheric models, however, our knowledge has advanced considerably. Noone et al. (1999) studied precipitation conditions in DML using ECMWF reanalysis data. They found that $89 \%$ of the days have low precipitation $\left(<0.2 \mathrm{~mm} \mathrm{~d}^{-1}\right)$, corresponding to $31 \%$ of the annual total, whereas only $1 \%$ of the days have high precipitation $\left(>1 \mathrm{~mm} \mathrm{~d}^{-1}\right)$ but account for $20 \%$ of the annual precipitation. High-precipitation days were shown to be connected to amplified upper-level planetary waves that direct moist air towards DML. Various studies have confirmed and extended these results for different parts of Antarctica. For example, it has been shown that a few snowfall events per year can be responsible for up to half of the annual total precipitation (Braaten, 2000; Reijmer and Van den Broeke, 2003; Fujita and Abe, 2006; Schlosser et al., 2010a; Gorodetskaya et al., 2013). In addition, Gorodetskaya et al. (2014) showed that atmospheric rivers play an important role in heavy precipitation events in Antarctica.

Synoptic events with blocking anticyclones were also described by Scarchilli et al. (2011), Massom et al. (2004), and Hirasawa et al. (2000). At the deep-drilling site Dome Fuji, while warm air advection combined with orographic lifting sometimes was not sufficient for precipitation formation, it did cause the removal of the prevalent temperature inversion layer by cloud formation that increased the downward long-wave radiation and by turbulent mixing (Enomoto et al., 1998; Hirasawa et al., 2000). Also, increased amounts of diamond dust can be observed after a synoptic snowfall event when moisture levels are still higher than on average (Hi- rasawa et al., 2013; Dittmann et al., 2016; Schlosser et al., 2016).

Dittmann et al. (2016) analyzed the only other daily precipitation / stable isotope ratio data set available in the interior of Antarctica, which was created in 2003 at the Japanese deep-drilling site Dome Fuji (Fujita and Abe, 2006). They investigated synoptic conditions during precipitation, estimated moisture source areas for precipitation events, and used MCIM to model the stable isotope ratios. Five typical weather situations for precipitation were defined. Approximately two-thirds of the days were directly or indirectly related to advection of moist air associated with amplification of the planetary waves. The model represented the observed annual cycle of $\delta^{18} \mathrm{O}$ and deuterium excess fairly well, but it underestimated the amount of fractionation between first evaporation at the oceanic moisture source and deposition at Dome Fuji. Nicolas and Bromwich (2011) similarly documented intrusions of warm maritime air into West Antarctica. Schlosser et al. (2004) investigated the influence of origin of precipitation on the delta- $T$ relationship using a 20 -year series of fresh snow samples at Neumayer Station, coastal DML. They calculated backward trajectories for three different arrival levels and compiled a classification of synoptic situations related to the precipitation events. The quality of the delta- $T$ relationship varied for the different trajectory classes (i.e., the differing moisture origins), and significant differences were found in both the delta- $T$ slopes and the deuterium excess for the different classes.

For ice core interpretation, these findings are important since they contradict the older assumption that precipitation in the interior Antarctica is predominantly diamond dust and thus exhibits only a weak seasonality. This implies that all seasons are represented evenly in the ice core. If, however, the synoptic snowfall occurs preferably in certain seasons and/or this preference is not constant in different climates, potentially a cold or warm bias would be found in the temperatures derived from stable water isotopes of an ice core. An understanding of the atmospheric circulation and its influence on precipitation conditions at deep-drilling sites is therefore essential for a correct interpretation of the ice core proxy data.

For Antarctica, only very few studies exist, that combine daily precipitation / fresh snow stable isotope data with meteorological conditions at the time of precipitation. The study at hand is the first to use a multiyear time series of such data for a deep ice core drilling site in the interior of the Antarctic continent.

\section{Study site}

Dome $\mathrm{C}\left(75.106^{\circ} \mathrm{S}, 123.346^{\circ} \mathrm{E}\right)$ is one of the major domes in East Antarctica, at an elevation of $3233 \mathrm{~m}$. Since 2005, a wintering base has been operated there jointly by France and Italy (Concordia Station). Dome $\mathrm{C}$ has a mean annual 
temperature of $-54.5^{\circ} \mathrm{C}$ (derived from $10 \mathrm{~m}$ snow temperature; mean temperature from AWSs from 1996 to 2015: $-51.3^{\circ} \mathrm{C}$ ) and a mean annual accumulation of $25 \mathrm{~mm}$ water equivalent (w.e.), the latter derived from ice cores. Dome $\mathrm{C}$ is the site where the so-far oldest ice has been retrieved during the European Project for Ice Coring in Antarctica (EPICA). After the first core, with a depth of $906 \mathrm{~m}$ covering ca. 32000 years, had been drilled in 1977-1978 (Lorius et al., 1979), several cores followed, and in January 2006 the EPICA drilling was completed at a depth of $3270.2 \mathrm{~m}$, yielding ice approximately 800000 years old. This core thus covers eight glacial cycles (EPICA community members, 2004), which doubles the time span that had been represented in the austral summer of 1977/78.

\section{Data and methods}

\subsection{Precipitation and stable isotope data}

Precipitation has been measured and sampled at Dome C since 2006 (with some interruptions in the early time period) and this sampling is ongoing. A wooden platform of approximately $1 \mathrm{~m}$ height, covered by a polystyrene/teflon plate, is used to measure daily precipitation amounts. The elevated platform is surrounded by a rail of $5 \mathrm{~cm}$ height. This helps to avoid contributions from low drifting snow but cannot prevent precipitated snow being removed completely and thus not measured - at higher wind speeds. The platform is located at a distance of $800 \mathrm{~m}$ from the main station. Until the end of 2007, the measurements were not carried out daily, and the samples were collected only when precipitation reached a certain threshold, which led to sampling intervals of 4 to 5 days. Since December 2007, however, precipitation has been sampled once per day at 01:00 UTC, and amounts and stable isotope ratios of the samples are determined. In this study we therefore consider the time period 2008-2010, with the more recent samples having not yet been analyzed at the time of our study. For this period, measurable precipitation was observed on $59 \%$ of all days, and stable isotope ratios were determined on $45 \%$ of the days.

Furthermore, the crystal type of the precipitation is analyzed, so that diamond dust, drift snow, and regular snowfall can be distinguished. Diamond dust forms due to radiative cooling of almost saturated air and consists of very fine needles. Mixing of a warmer, moister air mass with cold air can also lead to supersaturation of the cold air and consequent ice crystal formation. Synoptic snowfall is marked by various types of snow crystals that depend mainly on air temperature during crystal formation, whereas drift snow can be recognized by broken crystals. Also, a mixing of crystal types can be observed. Note that the precipitation amounts are so small that errors in quantification can amount to $100 \%$ or more. However, usually cases of diamond dust exhibit amounts 1 order of magnitude smaller than synoptic snowfall events.
To date, the Dome $\mathrm{C}$ precipitation data series, complemented by stable isotope measurements, represents the first and only multiyear precipitation series at an Antarctic deep-drilling site.

We note that $\delta^{17} \mathrm{O}$ and ${ }^{17} \mathrm{O}$ excess have been determined for a part of the samples, but the amount of data is not sufficient yet to get statistically significant results, and thus they are not used in the present study.

A detailed description of the measurements and a first analysis of the stable isotope data are provided by Stenni et al. (2016).

\subsection{AWS and radiosonde data}

Radiosonde data from the meteorological station at Dome C are used to determine the temperature at both the top of the surface inversion layer and the condensation level. The upper-air data are provided by the Meteo-Climatological Observatory of the Italian Antarctic Research Program (PNRA). Since the beginning of the measurements in 2005, a radiosonde has been launched every day at 12:00 UTC, unless excessive wind speeds prevent it. For each standard pressure level, geopotential height, air temperature, humidity, and wind are measured, and the data are delivered as TEMP files to the WMO (World Meteorological Organisation) Global Telecommunication System (GTS).

The current AWS, named Dome C II, was installed by the Antarctic Meteorological Research Center (AMRC) in 1995. The AMRC and AWS programs are sister projects of the University of Wisconsin-Madison, which are funded by the United States Antarctic Program (USAP). USAP provides real-time and archived weather observations and satellite imagery and supports a network of AWSs across Antarctica. At the AWS, standard meteorological variables, namely air temperature, surface pressure, wind speed and direction, and humidity, are measured. AWS data can be found at http://amrc.ssec.wisc.edu.

\subsection{Antarctic Mesoscale Prediction System (AMPS) archive data and trajectory calculation}

The AMPS (Powers et al., 2003, 2012) is a real-time numerical weather prediction system run to provide guidance for the weather forecasters of the USAP. It has been operated by the National Center for Atmospheric Research (NCAR) in support of the USAP since 2001, at first employing the polar version of the Fifth-Generation Pennsylvania State University/NCAR Mesoscale Model (Polar MM5). Since 2006 AMPS has used the Weather Research and Forecasting (WRF) model. The performance of WRF in AMPS and in Antarctica has been verified in a number of previous studies (see, e.g., Bromwich et al., 2005, 2013; Deb et al., 2016), while model output from AMPS has supported various Antarctic investigations (e.g., Powers, 2007; Nigro et al., 2011, 2012). The AMPS archive is the repository of gridded 
output from AMPS from over the years (Powers et al., 2012), and WRF gridded output from the archive has supported numerous studies (Seefeldt and Cassano, 2008, 2012; Schlosser et al., 2010a, 2016). Here, AMPS archive data from the period 2008-2010 are used here in analyses of the meteorological conditions affecting Dome $\mathrm{C}$ and its precipitation.

For the period analyzed in this study, the AMPS WRF configuration consisted of a nested domain setup with grids of 45 and $15 \mathrm{~km}$ horizontal spacing extending from the Southern Ocean poleward and covering the Antarctic continent, respectively. As the $15 \mathrm{~km}$ domain includes Dome $\mathrm{C}$, it is the output from this grid that is used for the analyses here. Vertical resolution in WRF for the study period reflected 44 levels from the surface to $10 \mathrm{hPa}$. The use of the AMPS archive data follows the methodology of a number of published studies analyzing conditions and regimes at ice core drilling sites across Antarctica (Schlosser et al., 2008, 2010b, 2016; Dittmann et al., 2016).

In this study, AMPS archive data are utilized to investigate the synoptic situation that lead to precipitation and to estimate moisture sources for the precipitation events. Fully three-dimensional 5-day back trajectories were calculated with the RIP4 software (Stoelinga, 2009) and together with $500 \mathrm{hPa}$ geopotential fields were used to estimate the moisture source. Conditions at the moisture source are then derived as input for the stable isotope modeling.

Trajectories were calculated for three different arrival levels: 300,500 , and $600 \mathrm{hPa}$. Since Dome C is situated at an elevation of $3233 \mathrm{~m}$ with a monthly mean surface pressure varying between 630 and $650 \mathrm{hPa}$ with daily values being considerably lower (lowest observed surface pressure: $603.6 \mathrm{hPa}$ ), the $600 \mathrm{hPa}$ level is the lowest standard pressure level that is always above the surface. For this location, it thus represents the flow close to the surface. Not shown are $300 \mathrm{hPa}$ trajectories since it was found that the moisture content at this level is already too low for producing any significant precipitation and the back trajectories hardly ever reached heights close to sea level. In this study, $500 \mathrm{hPa}$ is assumed to best represent the general atmospheric flow and synoptic-scale moisture transport.

\subsection{MCIM}

The so-called MCIM is a simple Rayleigh-type model that, however, allows the co-existence of water droplets and ice crystals and, as such, is the consequent further development of the basic distillation model established by Jouzel and Merlivat (Jouzel and Merlivat, 1984; Merlivat and Jouzel, 1979). It is still widely used in ice core studies and also is the basis for implementation of stable isotopes in GCMs or climate models. The model calculates fractionation in an isolated air parcel between the initial evaporation and the final precipitation. In contrast to a pure Rayleigh model, an adjustable part of the condensate stays in the cloud. In a likewise adjustable range of temperatures, both liquid droplets and ice crystals occur in the cloud, which causes additional kinetic fractionation processes due to the Bergeron-Findeisen effect: because of the different saturation vapor pressure with respect to ice and water, the actual vapor pressure lies between the saturation vapor pressure above water and that above the ice. This means a subsaturated environment for liquid water but a supersaturated environment for ice. This results in a net transport of water vapor from the droplets to the ice, with fractionation during evaporation from the droplets and deposition (i.e., negative sublimation) on the ice crystals. No fractionation is associated with freezing of liquid droplets since the freezing is rapid (Ciais and Jouzel, 1994). The initial isotopic composition of the vapor after the first evaporation is calculated assuming a balance between evaporation and condensation. Details about MCIM can be found in Ciais and Jouzel (1994) and Dittmann et al. (2016).

\section{Results}

\subsection{Meteorological conditions at Dome $\mathrm{C}$}

Figure 1 shows a histogram of daily precipitation amounts at Dome C for the period 2008-2010 derived from (a) measurements and (b) AMPS archive data. It shows a positively skewed distribution: in both model and observations, a large number of extremely small amounts are observed compared to only a few events with more than $0.2 \mathrm{~mm}$. The 90 and $95 \%$ percentiles are shown as possible thresholds for synoptically caused snowfall events. Note that the observational data refer basically to the precipitation sampling and cannot be corrected for cases where the wind speed was so high that no sampling was possible because the snow had been scoured from, or not accumulated at all, upon the platform. The small amounts most likely are associated with diamond dust formation, whereas the larger events are related to synoptically caused snowfall events (hereafter called "synoptic snowfall" events), which we will discuss in the next paragraph. Hoarfrost can have variable amounts depending on the amount of available moisture (see also Sect. 5.2). However, as can be seen in Fig. 2, hoarfrost mainly occurs in winter, at deep temperatures when absolute humidity is comparatively low. While 130 days with hoarfrost have temperatures between -60 and $-70^{\circ} \mathrm{C}$, about 70 hoarfrost days are in the temperature range -60 to $-50^{\circ} \mathrm{C}$; only less than 30 days show temperatures higher than $-50^{\circ} \mathrm{C}$. This means that hoarfrost does not have a specific fingerprint due to its crystal type and formation process, as stated in a preliminary study by Stenni et al. (2016), but, as speculated about qualitatively by Stenni et al. (2016) already, the different signal is due to the low temperatures prevailing at days with hoarfrost formation.

Note that Fig. 2 only displays the number of days with the observed precipitation type and does not take into account snowfall amounts. Snowfall days at higher temperatures are 

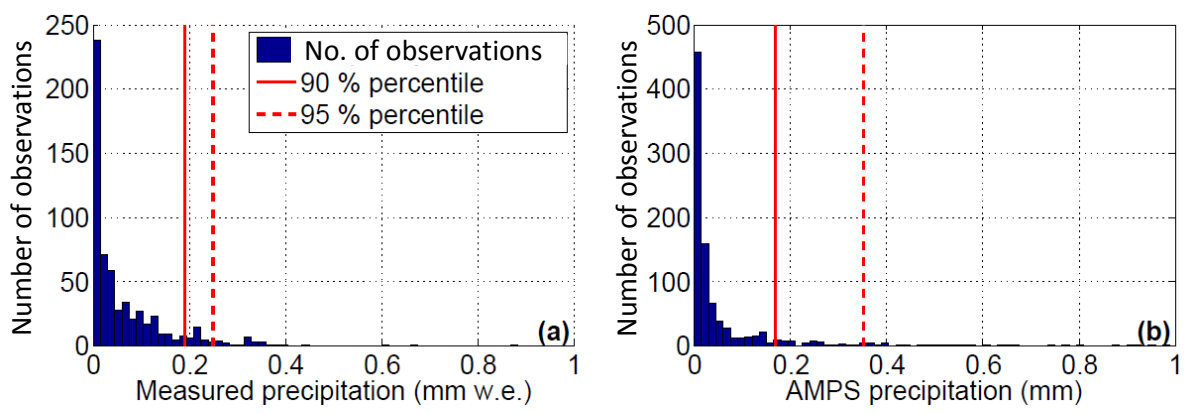

Figure 1. Histogram of daily precipitation amounts for (a) measurements and (b) AMPS archive data for the period 2008-2010.

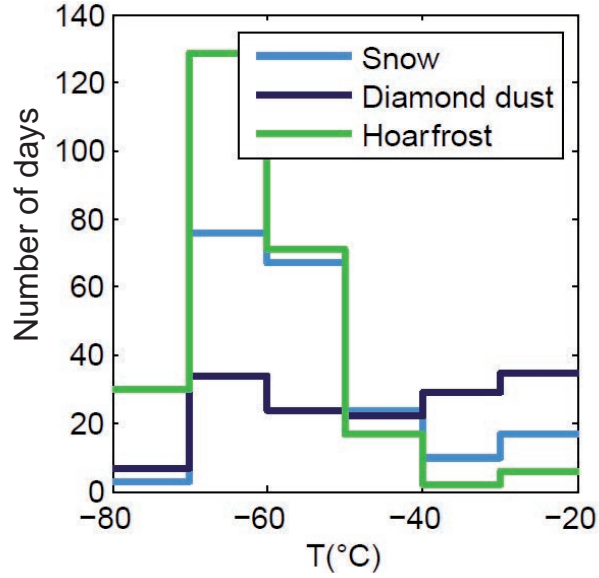

Figure 2. Frequency of the different precipitation types of observed precipitation.

less frequent than those at temperatures below $-50^{\circ} \mathrm{C}$ but usually have considerably larger amounts of precipitation.

Figure 3 displays the wind direction at the AWS Dome C II for (a) all days and (b) only observations with wind speeds above $10 \mathrm{~m} \mathrm{~s}^{-1}$. Dome $\mathrm{C}$ is the Antarctic location with the highest constancy in wind direction (Wendler and Kodama, 1984), even though no katabatic influence is found at the dome. Wind directions still show a preference for the SW sector, which can be explained by the climatological mean pressure distribution with an anticyclone prevailing above the continent that, on average, leads to approximately westerly to southerly winds at Dome C. For the higher wind speeds, the direction is much more variable, which demonstrates that the prevailing anticyclonic weather conditions are disturbed more often than previously thought.

\subsection{Synoptic patterns during precipitation}

Based on mainly $500 \mathrm{hPa}$ geopotential height from the AMPS archive, six different synoptic situations that lead to increased amounts of precipitation were classified. The classification was done manually because it allows the investigator to be in full control and oversight of the process and
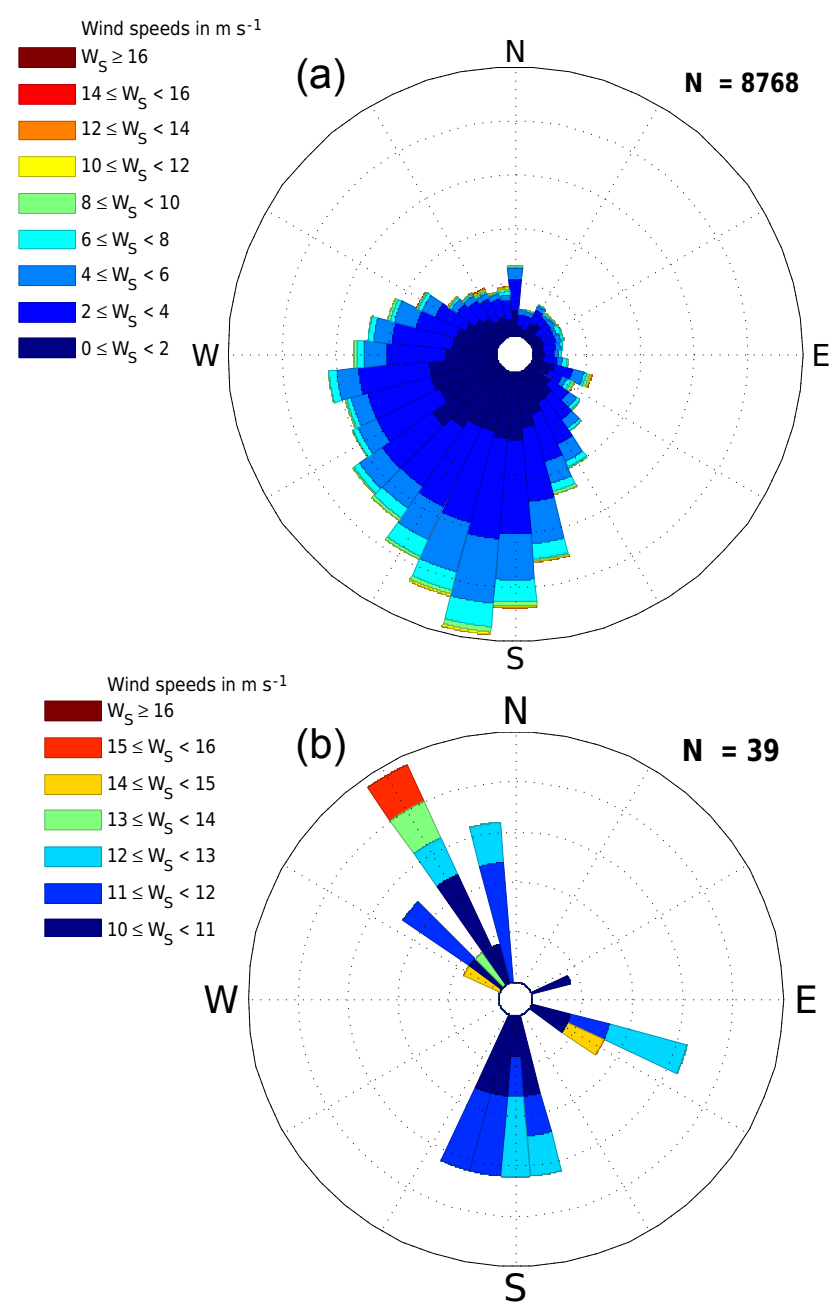

Figure 3. (a) Observed wind speed $W_{\mathrm{s}}$ and direction at Dome $\mathrm{C}$ AWS. (b) Observed wind speed $W_{\mathrm{S}}$ and direction for cases with wind speeds larger than $10 \mathrm{~ms}^{-1}$.

because the classification system can be tailored precisely to the researcher's needs. Figure 4 displays examples for these six classes: 

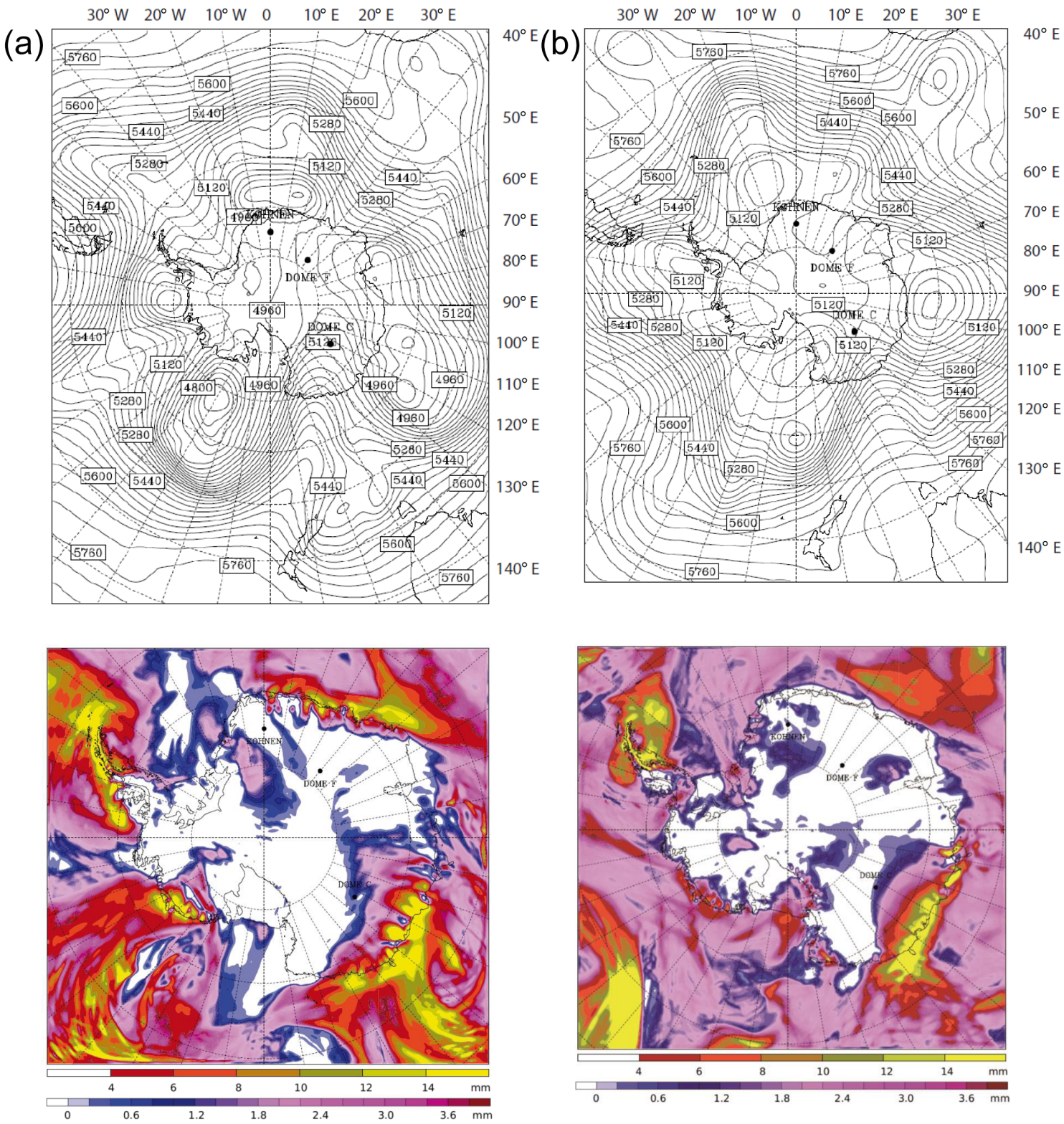

Figure 4.

a. Blocking anticyclone

Figure 4a shows the $500 \mathrm{hPa}$ geopotential height field for 23 May 2007, 00:00 UTC. A strong upper-level ridge is situated between $130^{\circ} \mathrm{E}$ and $160^{\circ} \mathrm{W}$, with the corresponding trough west of it and the ridge axis extending from NNW to SSE, which consequently brings Dome $\mathrm{C}$ into a strong northwesterly flow that originates at a latitude of approximately $45^{\circ} \mathrm{S}$. The relatively warm and moist air from these latitudes is orographically lifted above the Antarctic continent, which leads to cooling and precipitation formation. Even though only a small fraction of the original moisture arrives at Dome $\mathrm{C}$, it is enough to produce precipitation amounts about 1 order of magnitude larger than the more frequent diamond dust precipitation. The pattern lasted from 22 to 26 May 2007 in almost the same configuration, thus leading to a considerable amount of precipitation. Note that "considerable" on the high East Antarctic plateau, where annual precipitation is on the order of 20-30 $\mathrm{mm}$ water equivalent (w.e.), means $24 \mathrm{~h}$ precipitation amounts of $0.1-1.0 \mathrm{~mm}$ w.e. However, this synoptic precipitation is generally 1 order of magnitude higher than diamond dust precipitation, which usually exhibits values clearly below $0.1 \mathrm{~mm}$ w.e. The AMPS accumulated precipitation (12-36 h forecast from 22 May, 12:00 UTC, corresponding to the precipitation total for 

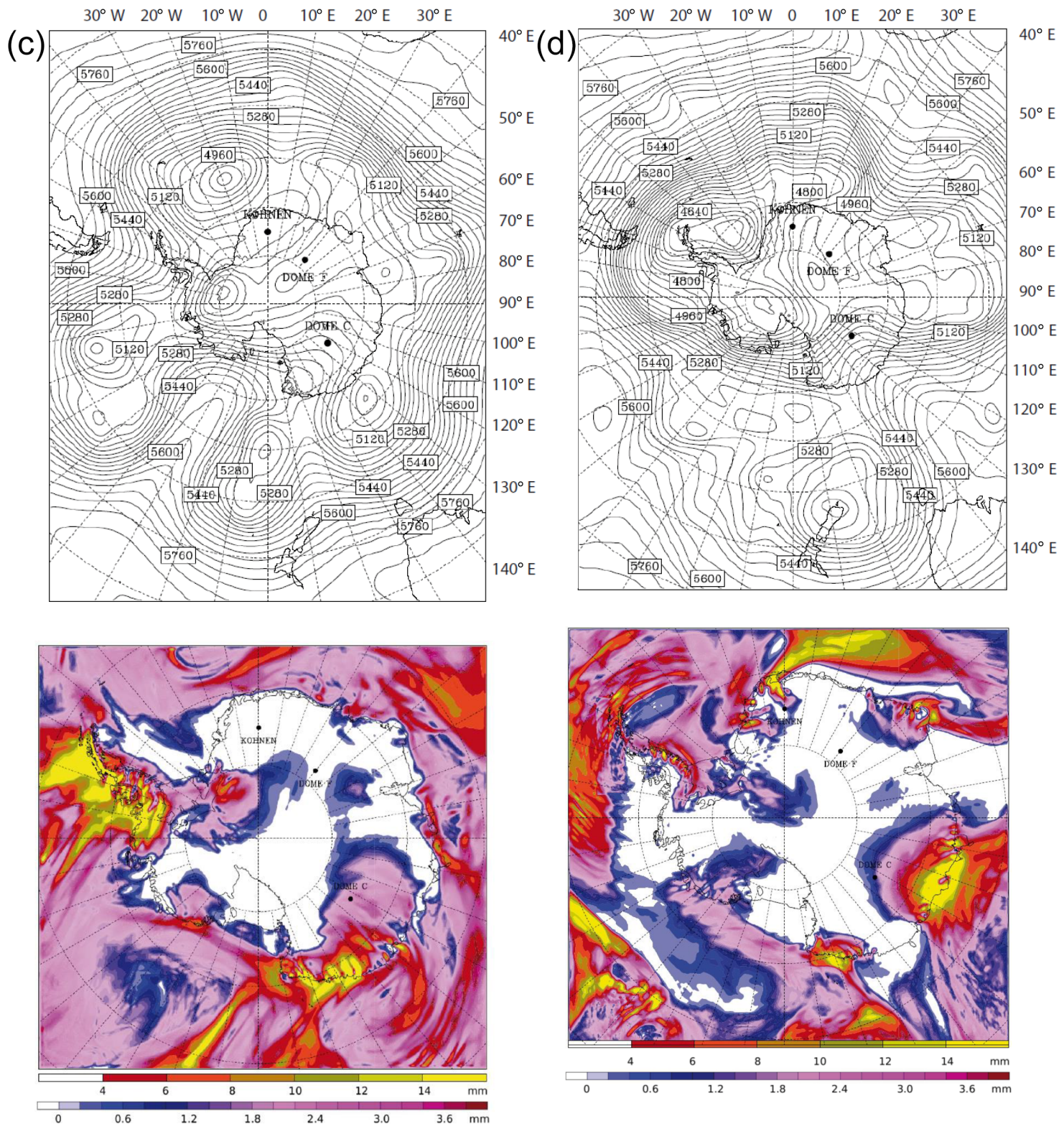

Figure 4.

the period 23 May, 00:00-24:00 UTC) is also shown. It can be clearly seen how precipitation decreases from the coast towards the interior but still reaches the high plateau.

b. Weak anticyclone with northwesterly flow

Figure $4 \mathrm{~b}$ displays similar fields as in Fig. 4a, the $500 \mathrm{hPa}$ geopotential for 13 February 2007, 00:00 UTC, and the $24 \mathrm{~h}$ precipitation for 13 February. The highpressure ridge, situated slightly farther to the west than in the previous case, is of smaller meridional extent than in the Fig. $4 \mathrm{a}$ and is less persistent, but principally the situation is fairly similar, with transport of moist, warm air in a northwesterly flow between an upper-level ridge and a trough from areas south of $50^{\circ} \mathrm{S}$. Those situations occur fairly frequently (order of magnitude: once per month, although with high interannual variability).

c. Anticyclone with northeasterly flow

In Fig. 4c a special case of the earlier examples is shown: specifically, the flow here is northeasterly rather than northwesterly. In this synoptic pattern, often a cutoff low or upper-level low is situated north or slightly northwest of the coast of Wilkes Land. The flow is directed around the cutoff low towards Dome C. While the distance to the coast is similar for a northwesterly 

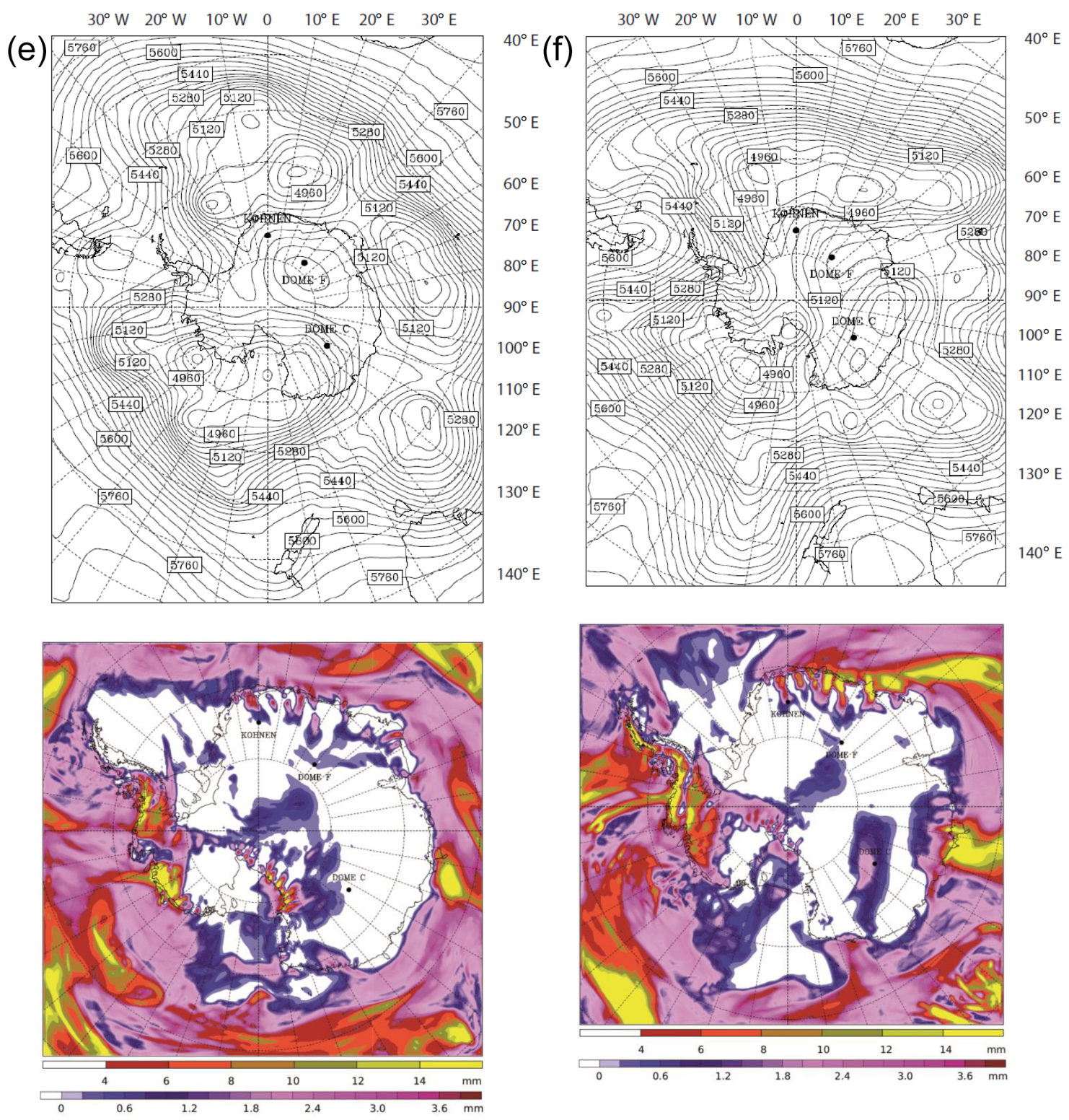

Figure 4. Synoptic patterns classification: $500 \mathrm{hPa}$ geopotential height (contour interval $10 \mathrm{gpm}$ ) and $24 \mathrm{~h}$ precipitation totals from AMPS archive for the different synoptic situations during precipitation: (a) blocking anticyclone with northwesterly flow (23 May 2007); (b) weak anticyclone with northwesterly flow (13 February 2007); (c) anticyclone with northeasterly flow (16 March 2007); (d) splitting of flow (14 August 2008); (e) southerly flow from West Antarctica (3 May 2007); (f) post-event (28 May 2007). The 500 hPa geopotential height fields stem from AMPS $12 \mathrm{~h}$ forecast of the preceding day, corresponding to 00:00 UTC of the described day; precipitation is AMPS 12-36 $\mathrm{h}$ forecast of the preceding day, corresponding to 00:00-24:00 UTC of the day described.

and a northeasterly flow, some dynamic lifting of the air mass above the ocean might be involved in addition to the orographic lifting. This should be studied in a future investigation.

\section{d. Splitting of flow}

In contrast to conditions determined from studies for Dome Fuji and Kohnen Station in DML, Dome C relatively often experiences a situation where the planetary waves are amplified, but the flow is split into a zonal part, in which Dome $\mathrm{C}$ is situated, and a meandering part with the strong trough and ridge in the amplified flow staying north of the Dome $\mathrm{C}$ region. While this leads to reduced advection of warm and moist air to Dome C, it can still cause precipitation formation. As the air mass originates farther south than in the cases described above, the meridional exchange of heat and moisture is smaller. 


\section{e. Flow from West Antarctica}

Another situation that has not been found at other deepdrilling sites is that relatively warm and moist air is advected to Dome $\mathrm{C}$ from the Amundsen-Bellingshausen seas across Marie Byrd Land. In the $500 \mathrm{hPa}$ geopotential height field in Fig. 5e a closed circulation centered in the Ross Sea can be seen, which leaves Dome C in a flow transporting air from the Amundsen Sea or north of it towards Dome C. For this situation, AMPS shows precipitation only in the vicinity of Dome $\mathrm{C}$, not at the station itself. This situation is most likely influenced by the strength and position of the Amundsen-Bellingshausen seas low (ASL; e.g., Raphael et al., 2016). Figure 5 shows the AMPS sea level pressure for 3 May 2007. In the described case, the ASL is found in a rather western position, corresponding to its usual annual cycle, which features a westernmost position in winter. A small but strong core is found in the western Amundsen Sea, accompanied by an upper-level low. Together with a weaker but broader low at surface and upper levels above the Ross Sea and beyond, this leads to a northerly flow at the eastern edge of the ASL, which continues over the continent towards Dome $\mathrm{C}$.

\section{f. Post-event increased moisture}

Several cases, for which AMPS shows very low or no precipitation, exhibit increased amounts of measured precipitation at Dome C. The precipitation was classified as diamond dust, but the events showed amounts that were atypically high for this type of precipitation. It was found that these cases, which did not show the northerly flow connected to advection of relatively warm and moist air, usually occurred after a synoptic snowfall event had happened. This implies that the available moisture was still increased, and AMPS shows a fairly large, isolated area of weak precipitation almost centered at Dome C.

\subsection{Wind speed and precipitation}

The AMPS wind direction for synoptic precipitation events only, identified in the AMPS data, is displayed in Fig. 6. Contrary to the average conditions displayed in Fig. 3, which have a pronounced preference for the southeast sector, for snowfall events the most frequent wind direction is NNW to NW, with almost no cases displaying flow from the SW sector. Also, the highest wind speeds $\left(12-14 \mathrm{~ms}^{-1}\right)$ are observed to come from a northwesterly direction. Here AMPS data rather than AWS data are used for this figure because the AMPS data were utilized to identify the high-precipitation events. In the observations, some cases with high precipitation were not found because they were accompanied by high wind speeds, and thus no sampling of the precipitation was possible after the snow had been blown off the measuring

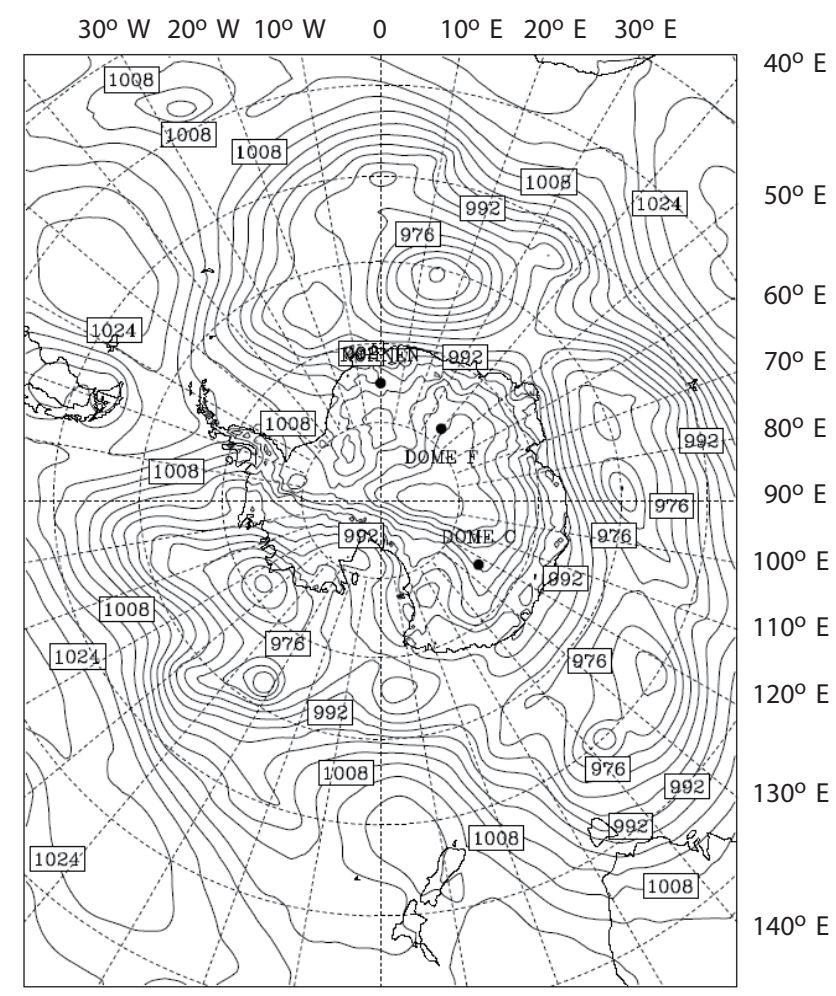

Figure 5. Sea level pressure from AMPS (domain 1) for 3 May 2007, 00:00 UTC.

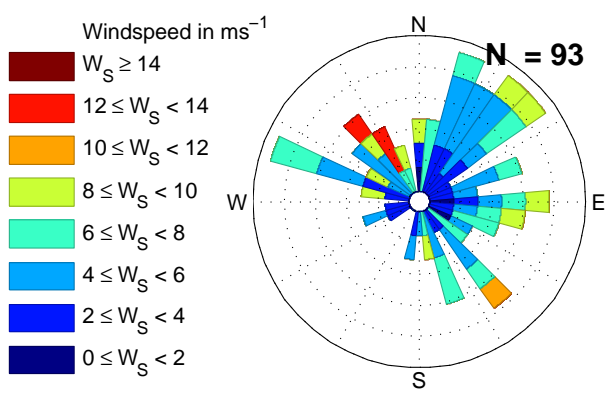

Figure 6. AMPS wind speed $W_{\mathrm{S}}$ and direction for snowfall events identified in AMPS data.

platform. Comparison of the total precipitation amount derived from the sampling to data from an accumulation stake array shows that the amount of sampled precipitation is lower than the measured accumulation. A study of the mismatches of AMPS and observation (i.e., where AMPS showed large precipitation amounts when no precipitation was reported in the observations) revealed that those cases usually showed an increase in temperature and wind speed observed at the AWS, indicating a synoptic disturbance. The annual number of such events varies between 3 in 2010 and 10 in 2008; in 2009, 8 events were identified in the AMPS data. The fact that those dates are not included in our analysis most likely does not 
weaken our results; on the contrary, since they are all related to synoptic disturbances, they would appear to rather emphasize our findings.

This wind influence also becomes clear from Fig. 7, in which the relationship between precipitation amounts and wind speed is illustrated. Precipitation amounts are related to wind speed for (a) observations and (b) AMPS archive data. Again, it has to be considered that days with high wind are mostly related to synoptic snowfall events that have high precipitation amounts in AMPS but cannot be seen in the observation since the snow has been blown off the measuring platform and thus not been recorded. Thus, Fig. $7 \mathrm{~b}$ seems to be more realistic than Fig. 7a, with larger precipitation amounts at correspondingly higher wind speeds. Surface mass balance data from firn cores and a stake array suggest that AMPS precipitation has a positive bias, whereas the total amounts measured at the platform are too low, which seems plausible considering the above mentioned mass losses due to removal of snow from the platform by the wind. Since all three methods have considerable error possibilities, we refrain from a more specific numeric quantification of these findings.

\subsection{Isotope measurements and modeling}

Figure 8a shows observed $\delta^{18} \mathrm{O}$ vs. $2 \mathrm{~m}$ air temperature for the different types of precipitation: snow, diamond dust, and hoarfrost. High-precipitation events, for which trajectories were calculated, are marked with circles. The regression lines differ only slightly for the various precipitation types. For all samples, a $\delta^{18} \mathrm{O}-T$ slope of $0.49 \%{ }^{\circ} \mathrm{C}^{-1}$ is found $(r=0.79$, $n=498)$. The slope for the studied high-precipitation events only is $0.39 \% 0^{\circ} \mathrm{C}^{-1}$, lower than for all days $(r=0.78, n=$ 21). Also, the relationship between deuterium excess and $\delta^{18} \mathrm{O}$ (Fig. 8b) shows no significant differences between the precipitation types. Slopes for the different crystal types are discussed in detail and compared to other Antarctic sites in Stenni et al. (2016) (modeled/observed values, daily/monthly values, inversion $/ 2 \mathrm{~m}$ temperature). At the time of our study, the time series of analyzed samples was not long enough to calculate statistically significant slopes for the different synoptic situations. Since the Dome C precipitation series is being continued this should be possible in the future. The only precipitation/stable isotope data series in Antarctica that is sufficiently long to get statistically significant results is that of Neumayer Station, coastal DML (Schlosser et al., 2004). This data series has meanwhile been extended to 36 years and is being reinvestigated.

In Fig. 9 the observed and modeled $\delta^{18} \mathrm{O}$ and deuterium excess for days with moisture source estimates are displayed. Observed $\delta^{18} \mathrm{O}$ and deuterium excess show a clear annual cycle. While $\delta^{18} \mathrm{O}$ exhibits a clear maximum in summer, the deuterium excess peaks in winter, most clearly in 2010, which was least disturbed by warm air intrusions. For the modeling of isotopic fractionation with MCIM, initial conditions at the moisture sources derived from a 5-day back- trajectory calculation combined with the synoptic flow analysis were used following the method described in Dittmann et al. (2016). Trajectories were calculated for all cases where the synoptic situation seemed to be suitable for it, meaning a rather clear atmospheric flow pattern. When this was not the case, trajectories tended to have kinks and loops and were not plausible or were suspect, and thus they were not included in the study.

The moisture sources for arrival levels 600 and $500 \mathrm{hPa}$ are shown in Fig. 10. Stronger colors correspond to higher frequency of occurrence of the respective moisture source. For cases in which the trajectory left the AMPS domain, ECMWF ERA-Interim reanalysis data were used to estimate the moisture source. For both arrival levels, the moisture source is found mainly in the $90-130^{\circ} \mathrm{E}$ longitude range of the Southern (Indian) Ocean. The most frequent latitude ranges are $40-50^{\circ} \mathrm{S}$ for $600 \mathrm{hPa}$ arrival level and $35-50^{\circ} \mathrm{S}$ for the $500 \mathrm{hPa}$ level. The model was run using different assumptions for the condensation temperature: (i) moisture source conditions derived for the estimate using the $500 \mathrm{hPa}$ back trajectory (arrival temperature of the trajectory at the $500 \mathrm{hPa}$ level; blue circles in Fig. 9), (ii) moisture source conditions derived for the estimate using the $600 \mathrm{hPa}$ back trajectory (arrival temperature at the $600 \mathrm{hPa}$ level; red circles), and (iii) moisture source estimated using the $500 \mathrm{hPa}$ trajectory (arrival temperature at the upper limit of the inversion layer derived from radiosonde data; green circles). For all model runs, the model parameters were kept constant. These parameters had been adapted to increase the calculated fractionation on the moisture transport path in order to get the best agreement of modeled and observed values. The slope of the supersaturation over ice was set to zero and the parameters determining the amount of precipitation leaving the cloud were set close to Raleigh conditions. The modeled $\delta^{18} \mathrm{O}$ values are generally too high, no matter which assumption is made for the condensation temperature. Using the $500 \mathrm{hPa}$ data yields a smaller bias but a lower correlation between the observed and modeled $\delta^{18} \mathrm{O}$ than using the $600 \mathrm{hPa}$ temperatures and moisture source assumptions $(R=0.61$ and bias $=3 \%$ for $500 \mathrm{hPa}$ and $R=0.74$ and bias $=11.3 \%$ ofor $600 \mathrm{hPa} ; p<0.05$ ). The corresponding values for use of the inversion temperature are $R=0.66$ $(p<0.05)$ and bias $=10.5 \%$ o. An attempt to use the condensation temperature at Dome $\mathrm{C}$ derived from radiosonde data as model input (rather than inversion temperature or temperature at the arrival levels of the calculated trajectories) did not improve the correlation between observed and modeled isotope ratios: no statistically significant correlation between modeled and observed $\delta^{18} \mathrm{O}$ was found in this case. The correlation of condensation temperature $T_{\mathrm{C}}$ and $2 \mathrm{~m}$ temperature $T_{2 \mathrm{~m}}$ was clearly weaker than the correlation of $T_{\mathrm{inv}}, T_{500}$, and $T_{600}$ with $T_{2} \mathrm{~m}$. Since $T_{2 \mathrm{~m}}$ and observed $\delta^{18} \mathrm{O}$ were well correlated, it could not be expected that using $T_{\mathrm{C}}$ in the model would yield better results for the stable isotope ratios. $T_{\mathrm{C}}$ also showed a weaker annual cycle than $T_{\mathrm{inv}}$. Modeled and ob- 

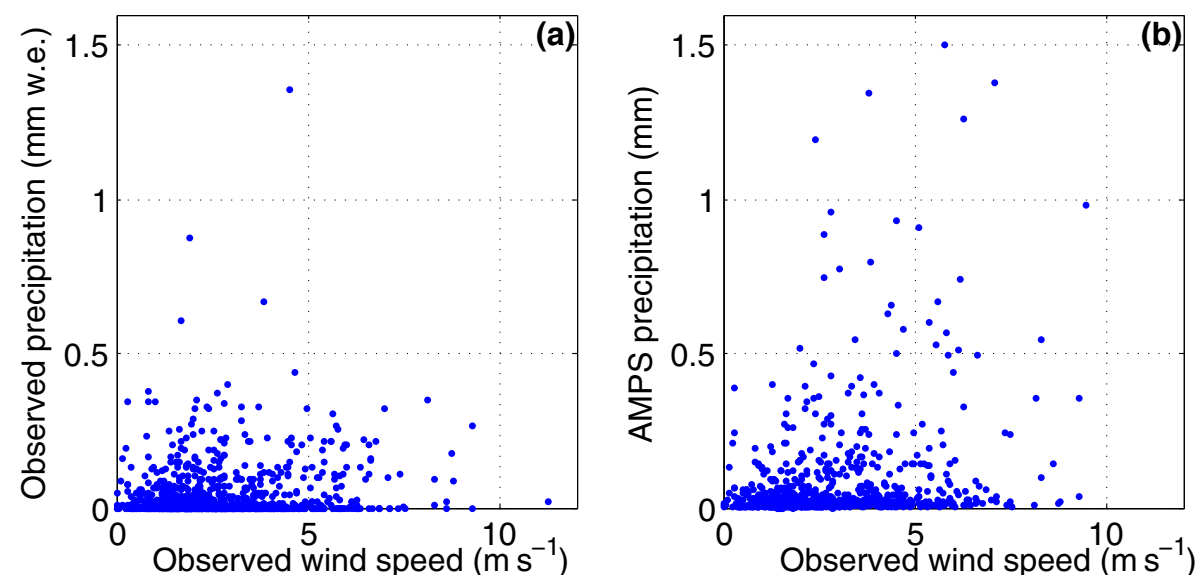

Figure 7. Observed wind speed at AWS vs. observed and modeled $24 \mathrm{~h}$ precipitation at Dome C.
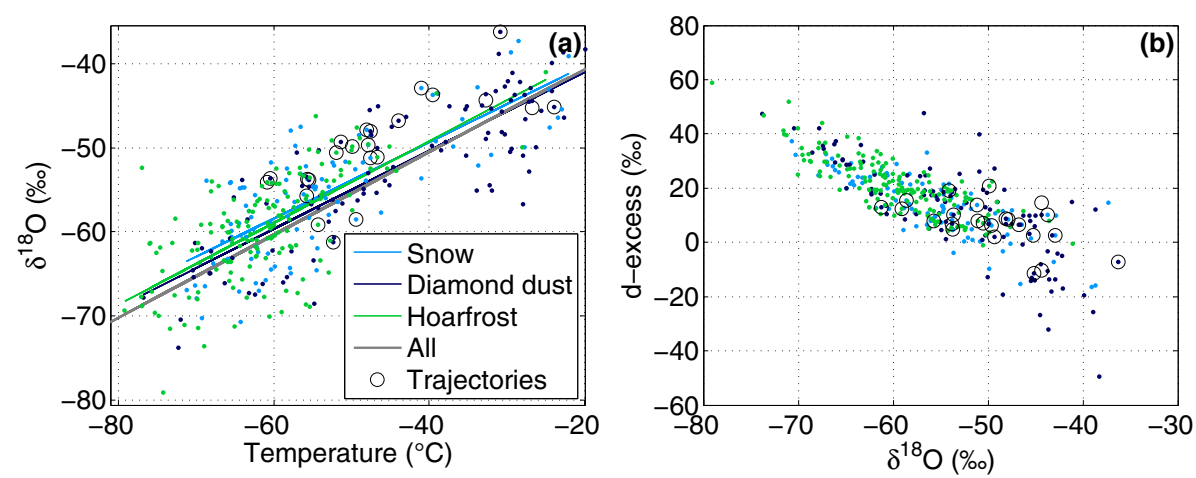

Figure 8. (a) $\delta^{18} \mathrm{O}$ of precipitation samples vs. $2 \mathrm{~m}$ air temperature from an AWS for the different types of precipitation, snow, diamond dust, and hoarfrost. High-precipitation events, for which trajectories were calculated, are marked with circles. (b) $\delta^{18} \mathrm{O}$ of precipitation samples vs. deuterium excess.

served deuterium excess show a weak correlation only when the inversion temperature is used as condensation temperature $(R=0.51, p=0.02)$. Ekaykin and Lipenkov (2009) investigated the relationship between the inversion temperature and the $2 \mathrm{~m}$ temperature and their correlation with stable isotope ratios for longer timescales. They state that in central Antarctica the condensation temperature is considerably lower than the temperature at the top of the inversion layer, since diamond dust forms throughout the inversion layer. However, this should not matter in our case because for the modeling we considered cases of synoptic snowfall rather than diamond dust formation.

It should be kept in mind, though, that MCIM is a relatively simple model with various strong simplifications, such as assumptions of a single moisture source, a single temperature inversion, and a humidity inversion parallel to the temperature inversion. Additionally, it is assumed that the $500 \mathrm{hPa}$ level is representative for the general moisture transport, which is likely, but maybe not true in all cases. Also, while the moisture source is estimated as exactly as possible, there might be errors here that could also lead to a weaker agreement of modeled and observed stable isotope ratios. Lastly, the determination of the lifting condensation level using radiosonde data in the extremely dry atmosphere above Dome $\mathrm{C}$ is a challenge and may also introduce errors.

\section{Comparison of Dome C and Dome Fuji}

Dome $\mathrm{C}$ and Dome Fuji are both deep ice core drilling sites with the oldest ice ever drilled on earth $(800000$ and 720000 years, respectively; EPICA community members, 2004; Motoyama, 2007). At $3810 \mathrm{~m}$ altitude and $77.31^{\circ} \mathrm{S}$, $39.70^{\circ} \mathrm{E}$, Dome Fuji is situated slightly further south and at an approximately $600 \mathrm{~m}$ higher elevation than Dome C. Consequently, Dome Fuji has a slightly lower mean annual temperature of $-57.7^{\circ} \mathrm{C}$ (compared to $-54.5^{\circ} \mathrm{C}$ at Dome C). Accumulation rates are very similar $(25 \mathrm{~mm}$ for Dome C, $27 \mathrm{~mm}$ for Dome Fuji). Generally both locations experience the same extremely dry and cold climate of the high East Antarctic Plateau. Being on top of a topographic dome, neither one is under the influence of katabatic flow. 

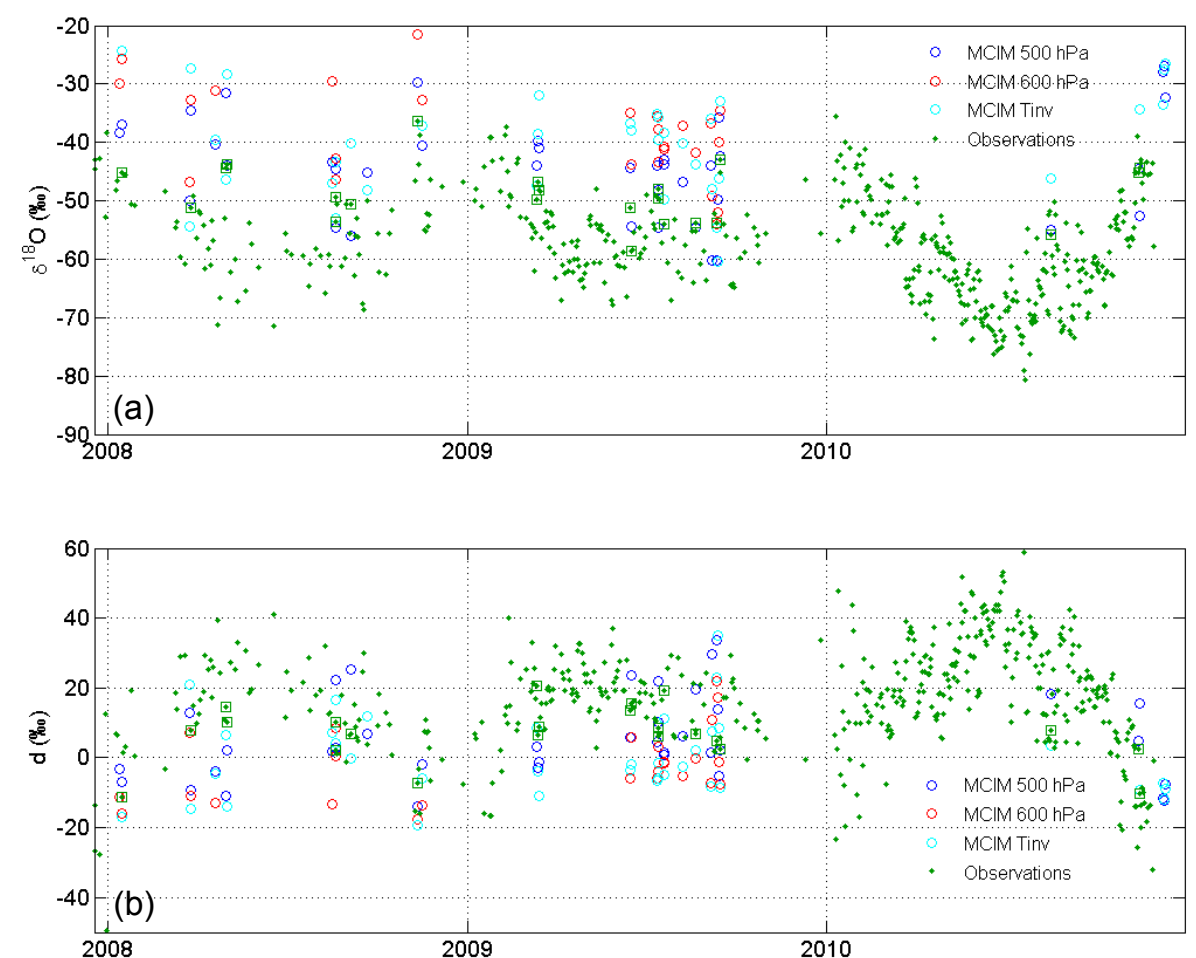

Figure 9. Observed and modeled (a) $\delta^{18} \mathrm{O}$ and (b) deuterium excess for days with moisture source estimates with Dome $\mathrm{C}$ temperature taken at $500 \mathrm{hPa}$ level, $600 \mathrm{hPa}$ level, and at the upper limit of the temperature inversion layer (derived from radiosondes as described in the text). The green squares mark cases for which trajectory calculations were carried out.
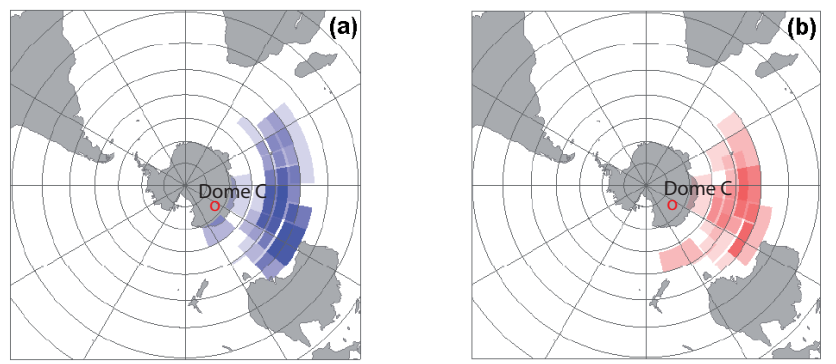

Figure 10. Estimated moisture source areas for arrival levels (a) $600 \mathrm{hPa}$ and (b) $500 \mathrm{hPa}$. Stronger color corresponds to higher frequency of occurrence of the respective moisture source.

Whereas daily precipitation measurements are available at Dome Fuji for only 1 year, the Dome $\mathrm{C}$ series is a multiyear time series having been continued to the present. For our study, the years 2008-2010 were analyzed. In addition to the type of data used in the Dome Fuji study, at Dome C upper-air data and crystal type data were available for our study. The synoptic situations responsible for precipitation are fairly similar for both stations (basically related to amplified Rossby waves); however, cases specific to either Dome C or Dome Fuji do occur: Whereas for Dome Fuji this refers to a situation with moisture advection from the south (via Kohnen Station, another deep-drilling site; Schlosser et al., 2010a, b), for Dome C the moisture is advected via West Antarctica and the flow related to the ASL. The latter is of special importance for glacial periods when the topography of the ice sheet was different from today.

The case of splitting of the flow (Fig. 4d) did not occur in the Dome Fuji study, but, given the shortness of the investigation period, we cannot rule out the possibility that this situation also occurs in the Dome Fuji area.

Our study generally confirms the results of the Dome Fuji study. Both studies pointed out that the synoptic situation of amplified waves with strongly developed troughs and ridges lead to increased meridional exchange of heat and moisture. For interpretation of stable isotope profiles from ice cores, this means that a more northern moisture source does not necessarily mean a stronger depletion in heavy isotopes since the temperature difference between moisture source and deposition site is reduced. Also, based on daily values or precipitation events, no correlation between deuterium excess and moisture source conditions could be found for either location. Most earlier studies deal with longer time periods (from at least monthly-seasonal to glacial-interglacial changes). 


\section{Discussion and conclusion}

The first and only multiyear data series of daily precipitation amounts, precipitation type, and stable isotope ratios at an Antarctic deep ice core drilling site was combined with output from a mesoscale atmospheric model and a simple isotope model to study the influence of the precipitation regime on the corresponding stable water isotope ratios.

Here we present the first complete classification of synoptic patterns for precipitation events at Dome C for 20082010. Snowfall events with precipitation amounts an order of magnitude larger than diamond dust precipitation were often associated with amplification of Rossby waves in the circumpolar trough with increased meridional transport of heat and moisture.

In contrast to other deep-drilling sites in East Antarctica, such as Dome Fuji (Dittmann et al., 2016) and Kohnen (Schlosser et al., 2010a, b), at Dome $\mathrm{C}$ in some cases a moisture transport from West Antarctica across the continent occurred. This is particularly interesting due to its relation to the ASL. Strength and location of the ASL have a strong influence on meridional exchange of heat and moisture in West Antarctica (Raphael et al., 2016).

The $\delta^{18} \mathrm{O}-T$ relationship did not differ considerably between the different precipitation types: snowfall, diamond dust, and hoarfrost showed almost similar slopes. Hoarfrost exhibited significantly lower $\delta^{18} \mathrm{O}$ and $\delta \mathrm{D}$ values and higher deuterium excess than snowfall and diamond dust. Whereas Stenni et al. (2016) state that hoarfrost has a distinct fingerprint among the various precipitation types, implying that moisture sources and or the hydrological cycle might be different for hoarfrost, our current, more detailed study has shown that this "fingerprint" is due to the fact that hoarfrost occurs predominantly during the cold period. Relatively large amounts of hoarfrost are measured after synoptic snowfall events, when humidity is still increased after moisture transport from lower latitudes, implying that hoarfrost basically has the same moisture sources as the other precipitation types. The local cycle of sublimation and deposition of hoarfrost is still fairly unknown but seems to be a process in which the depletion and enrichment of heavier isotopes are reversible. This leads to the conclusion that since there is no moisture source on the continent, the moisture responsible for diamond dust and hoarfrost formation has to be transported on similar pathways as synoptic snowfall to the interior of the continent.

Note that diamond dust is not parameterized in the WRF model used in AMPS. Nevertheless the model output used here yields only 6 days with no precipitation at all in the study period.

Modeled stable isotope ratios showed a "warm" bias compared to the observations, which was also found in previous similar studies (e.g., Steen-Larsen et al., 2017).

However, using the condensation temperature at Dome $\mathrm{C}$ derived from radiosonde data as model input (rather than the temperature at the top of the inversion layer or the temperature at the arrival levels of the calculated trajectories) did not improve the correlation between observed and modeled isotope ratios; in fact, the correlation coefficient decreased considerably and was no longer significant, most likely because the condensation temperature determined from the radiosonde data displayed only a weak annual cycle. More detailed studies of vertical humidity and temperature profiles during precipitation are necessary to understand this result. However, at present, no explanation for this can be offered. The assumption generally used in ice core studies (e.g., Stenni et al., 2016) that the temperature at the top of the inversion layer represents the condensation temperature could not be proven.

No correlation was found between observed deuterium excess and relative humidity at the estimated moisture source, which is contradictory to measurements by Uemura et al. (2008) and Steen-Larsen et al. (2014). Whether this has general physical reasons or is due to the fact that we studied individual events or to errors in moisture source estimation cannot be determined with the given data set.

It was also found that a more northern moisture source does not - as commonly assumed - necessarily mean stronger depletion of heavy isotopes, since the advection of warm air associated with snowfall events reduces the temperature difference between oceanic moisture source and deposition site and thus reduces the strength of the distillation. This confirms the recent results of Dittmann et al. (2016) found at the deep-drilling site Dome Fuji for a 1-year time period.

With the extension of the data series in the future it will be possible to calculate statistically significant delta- $T$ slopes for the different synoptic situations. Combined with simulations of the past climate with GCMs this will lead to a more exact quantitative interpretation of stable isotope profiles from deep ice cores. However, more multiyear precipitation data sets are needed in Antarctica for a better spatial representativeness.

Data availability. The precipitation amount and stable isotope data are available as a Supplement to Stenni et al. (2016) at https://www.the-cryosphere.net/10/2415/2016/. AWS data are from US AWS Dome C II (http://amrc.ssec.wisc.edu). AMPS archive data are available from http://www2.mmm.ucar.edu/rt/ amps/information/amps_archive_hpss_details.html or via kmanning@ucar.edu. Radiosonde data from Dome C are available on request from www.climatantartide.it via paolo.grigioni@enea.it.

Author contributions. BS is responsible for the precipitation measurements and stable isotope analysis, MV and AC for the crystal analysis, and PG and CS for the radiosonde data provision and analysis. AD carried out the stable isotope modelling, with contributions by VMD, and the comparisons of observations with modeled meteorological and isotope data. ES did the analysis of synoptic patterns, 
where AMPS data analysis was supported by JGP and KWM. The manuscript was prepared by ES, AD, JGP, and KWM with constructive comments of the other co-authors.

Competing interests. The authors declare that they have no conflict of interest.

Acknowledgements. This study was funded by the Austrian Science Funds (FWF) under grants P24223 and P28695. AMPS is supported by the US National Science Foundation, Division of Polar Programs. The precipitation measurements at Dome $\mathrm{C}$ have been carried out in the framework of the Concordia station and ESF PolarCLIMATE HOLOCLIP projects. We appreciate the support of the University of Wisconsin-Madison Automatic Weather Station Program with the Dome C II data set (NSF grant numbers ANT0944018 and ANT-12456663). Radiosonde data and information were obtained from IPEV/PNRA Project "Routine Meteorological Observation at Station Concordia" (www.climantartide.it). We would like to express our gratitude to all winterers at Dome $\mathrm{C}$, who were involved in the precipitation sampling.

Edited by: Joel Savarino

Reviewed by: two anonymous referees

\section{References}

Altnau, S., Schlosser, E., Isaksson, E., and Divine, D.: Climatic signals from 76 shallow firn cores in Dronning Maud Land, East Antarctica, The Cryosphere, 9, 925-944, https://doi.org/10.5194/tc-9-925-2015, 2015.

Bonne, J.-L., Masson-Delmotte, V., Cattani, O., Delmotte, M., Risi, C., Sodemann, H., and Steen-Larsen, H. C.: The isotopic composition of water vapour and precipitation in Ivittuut, southern Greenland, Atmos. Chem. Phys., 14, 4419-4439, https://doi.org/10.5194/acp-14-4419-2014, 2014.

Bonne, J. L., Steen-Larsen, H. C., Risi, C., Werner, M., Sodemann, H., Lacour, J. L., Fettweis, X., Cesana, G., Delmotte, M., Cattani, O., Vallelonga, P., Kjaer, H. A., Clerbaux, C., Sveinbjörnsdóttir, Á. E., and Masson-Delmotte, V.: The summer 2012 Greenland heat wave: In situ and remote sensing observations of water vapour isotopic composition during an atmospheric river event, J. Geophys. Res., 120, 2970-2989, https://doi.org/10.1002/2014JD022602, 2015.

Braaten, D. A.: Direct measurements of episodic snow accumulation on the Antarctic polar plateau, J. Geophys. Res., 105, 10119-10128, 2000.

Bromwich, D. H., Monaghan, A. J., Manning, K. W., and Powers, J. G.: Real-time forecasting for the Antarctic: An evaluation of the Antarctic Mesoscale Prediction System (AMPS), Mon. Weather Rev., 133, 579-603, 2005.

Bromwich, D. H., Otieno, F. O., Hines, K. M., Manning, K. W., and Shilo, E.: Comprehensive evaluation of polar weather research and forecasting performance in the Antarctic, J. Geophys. Res., 118, 274-292, https://doi.org/10.1029/2012JD018139, 2013.

Casado, M., Landais, A., Masson-Delmotte, V., Genthon, C., Kerstel, E., Kassi, S., Arnaud, L., Picard, G., Prie, F., Cattani, O.,
Steen-Larsen, H.-C., Vignon, E., and Cermak, P.: Continuous measurements of isotopic composition of water vapour on the East Antarctic Plateau, Atmos. Chem. Phys., 16, 8521-8538, https://doi.org/10.5194/acp-16-8521-2016, 2016 a.

Casado, M., Landais, A., Picard, G., Münch, T., Laepple, T., Stenni, B., Dreossi, G., Ekaykin, A., Arnaud, L., Genthon, C., Touzeau, A., Masson-Delmotte, V., and Jouzel, J.: Archival of the water stable isotope signal in East Antarctic ice cores, The Cryosphere Discuss., https://doi.org/10.5194/tc-2016-263, 2016 b.

Church, J. A., Gregory, J. M. (Coord. Lead Authors), Huybrechts, P., Kuhn, M., Lambeck, K., Nhuan, M. T., Quin, D., Woolworth, P. L. (Lead Authors), Anisimov, O. A., Bryan, F. O., Cazenave, A., Dixon, K. W., Fitzharris, B. B., Flato, G. M., Ganopolski, A., Gornitz, V., Lowe, J. A., Oberhuber, J. M., O'Farell, S. P., Omuhra, A., Oppenheimer, M., Peltier, W. R., Raper, S. C. B., Ritz, C., Schlosser, E., Shum, C. K., Stocker, T. F., Stouffer, R. J., Voss, R., van de Wal, R. S. W., Wiebe, E. C., Wild, M., Wingham, D. J., and Zwally, H. J. (Contributing Authors): Sea Level Change, in: Climate Change 2013: The Physical Science Basis. Contribution of Working Group I to the Fifth Assessment Report of the Intergovernmental Panel on Climate Change, edited by: Stocker, T. F., Qin, D., Plattner, G. K., Tignor, M., Allen, S. K., Boschung, J., Nauels, A., Xia, Y., Bex, V., and Midgley, P. M., Cambridge University Press, Cambridge, United Kingdom and New York, NY, USA, 2013.

Ciais, P. and Jouzel, J.: Deuterium and oxygen 18 in precipitation: Isotopic model, including mixed cloud processes, J. Geophys. Res., 99, 16793-16803, 1994.

Dansgaard, W.: Stable isotopes in precipitation, Tellus, XVI, 436468, 1964.

Deb, P., Orr, A., Hosking, J. S., Phillips, T., Turner, J., Bannister, D., Pope, J. O., and Colwell, S.: An assessment of the Polar Weather Research and Forecasting WRF) Model representation of near-surface meteorological variables over West Antarctica, J. Geophys. Res.-Atmos., 121, 1532-1548, https://doi.org/10.1002/2015JD024037, 2016.

Dittmann, A., Schlosser, E., Masson-Delmotte, V., Powers, J. G., Manning, K. W., Werner, M., and Fujita, K.: Precipitation regime and stable isotopes at Dome Fuji, East Antarctica, Atmos. Chem. Phys., 16, 6883-6900, https://doi.org/10.5194/acp16-6883-2016, 2016.

Ebner, P. P., Steen-Larsen, H. C., Stenni, B., Schneebeli, M., and Steinfeld, A.: Experimental observation of transient $\delta^{18} \mathrm{O}$ interaction between snow and advective airflow under various temperature gradient conditions, The Cryosphere, 11, 1733-1743, https://doi.org/10.5194/tc-11-1733-2017, 2017.

Ekaykin, A. A. and Lipenkov, V. Y.: Formation of the Ice Core Isotopic Composition, Low Temperature Science, 68, 299-314, 2009.

Enomoto, H., Motoyama, H., Shiraiwa, T., Saito, T., Kameda, T., Furukawa, T., Takahashi, S., Kodama, Y., and Watanabe, O.: Winter warming over Dome Fuji, East Antarctica and semiannual oscillation in the atmospheric circulation, J. Geophys. Res., 103, 23103-23111, 1998.

EPICA community members: 8 Glacial cycles from an Antarctic ice core, Nature, 429, 623-628, 2004.

Frieler, K., Clark, P. U., He, F., Buizert, C., Reese, R., Ligtenberg, S. R. M., Van den Broeke, M. R., Winkelmann, R., and Levermann, A.: Consistent evidence of increasing Antarctic ac- 
cumulation with warming, Nature Clim. Change, 5, 348-352, https://doi.org/10.1038/NCLIMATE2574, 2015.

Fudge, T. J., Markle, B. R., Cuffey, K. M., Buizert, C., Taylor, K. C., Steig, E. J., Waddington, E. D., Conway, H., and Koutnik, M.: Variable relationship between accumulation and temperature in West Antarctica for the past 31,000 years, Geophys. Res. Lett., 43, 3795-3803, https://doi.org/10.1002/2016GL068356, 2016.

Fujita, K. and Abe, O.: Stable isotopes in daily precipitation at Dome Fuji, East Antarctica, Geophys. Res. Lett., 33, L18503, https://doi.org/10.1029/2006GL026936, 2006.

Gorodetskaya, I. V., Van Lipzig, N. P. M., Van den Broeke, M. R., Mangold, A., Boot, W., and Reijmer, C. H.: Meteorological regimes and accumulation patterns at Utsteinen, Dronning Maud Land, East Antarctica: Analysis of two contrasting years, J. Geophys. Res., 118, 1-16, https://doi.org/10.1002/jgrd.50177, 2013.

Gorodetskaya, I. V., Tsukernik, M., Claes, K., Ralph, M. F., Neff, W. D., and van Lipzig, N. P. M.: The role of atmospheric rivers in anomalous snow accumulation in East Antarctica, Geophys. Res. Lett., 41, 6199-6206, https://doi.org/10.1002/2014GL060881, 2014.

Hirasawa, N., Nakamura, H., and Yamanouchi, T.: Abrupt changes in meteorological conditions observed at an inland Antarctic station in association with wintertime blocking, Geophys. Res. Lett., 27, 1911-1914, 2000

Hirasawa, N., Nakamura, H., Motoyama, H., Hayashi, M., and Yamanouchi, T.: The role of synoptic-scale features and advection in a prolonged warming and generation of different forms of precipitation at dome Fuji station, Antarctica, following a prominent blocking event, J. Geophys. Res., 118, 6916-6928, https://doi.org/10.1002/jgrd.50532, 2013.

Jouzel, J. and Merlivat, L.: Deuterium and oxygen 18 in precipitation: Modelling of the isotopic effects during snow formation, J. Geophys. Res., 89, 11749-11757, 1984.

Jouzel, J., Alley, R. B., Cuffey, K. M., Dansgaard, W., Grootes, P., Hoffmann, G., Johnsen, S. J., Koster, R. D., Peel, D., Shuman, A., Stievenard, M., Stuiver, M., and White, J.: Validity of the temperature reconstruction from water isotopes in ice cores, J. Geophys. Res., 102, 26471-26487, 1997.

Kavanaugh, J. L. and Cuffey, K. M.: Space and time variation of ${ }^{18} \mathrm{O}$ and $\delta \mathrm{D}$ in Antarctic precipitation revisited, Global Biogeochem. Cy., 17, 1017, https://doi.org/10.1029/2002GB001910, 2003.

Kuettel, M., Steig, E., Ding, Q., Monaghan, A. J., and Battisti, D. S.: Seasonal climate information preserved in West Antarctic ice core water isotopes: relationships to temperature, largescale circulation, and sea ice, Clim. Dynam., 39, 1841-1857, https://doi.org/10.1007/s00382-012-1460-7, 2012.

Landais, A., Barkan, E., and Luz, B.: Record of $\delta^{18} \mathrm{O}$ and ${ }^{17} \mathrm{O}$-excess in ice from Vostok Antarctica during the last 150,000 years, Geophys. Res. Lett., 35, L02709, https://doi.org/10.1029/2007GL032096, 2008.

Landais, A., Steen-Larsen, H. C., Guillevic, M., Masson-Delmotte, V., Vinther, B., and Winkler, R.: Triple isotopic composition of oxygen in surface snow and water vapor at NEEM (Greenland), Geochim. Cosmochim. Ac., 77, 304-316, 2012.

Lorius, C., Merlivat, L., Jouzel, J., and Pourchet, M.: A 30,000 years isotope climatic record from Antarctic ice, Nature, 280, 644-647, 1979.
Massom, R., Pook, M. J., Comiso, J. C., Adams, N., Turner, J., Lachlan-Cope, T., and Gibson, T.: Precipitation over the interior East Antarctic ice sheet related to midlatitude blocking-high activity, J. Climate, 17, 1914-1928, 2004.

Masson-Delmotte, V., Shugui, H., Ekaykin, A., Jouzel, J., Aristarain, A., Bernardo, R. T., Bromwich, D. H., Cattani, O., Delmotte, M., Falourd, S., Frezotti, M., Gallée, H., Genoni, L., Landais, A., Helsen, M., Hoffmann, G., Morgan, V., Motoyama, H., Noone, D., Oerter, H., Petit, J. R., Royer, A., Ruemura, R., Schmidt, G., Schlosser, E., Simoes, J., Steig, E., Stenni, B., Stievenard, M., Vimeux, F., and White, J. W. C.: A review of Antarctic surface snow isotopic composition: observations, atmospheric circulation and isotopic modelling. J. Climate, 21, 3359-3387, https://doi.org/10.1175/2007JCLI2139.1, 2008.

Merlivat, L. and Jouzel, J.: Global climatic interpretation of the deuterium-oxygen 18 relationship for precipitation, J. Geophys. Res., 84, 5029-5033, 1979.

Motoyama, H.: The Second Deep Ice Coring Project at Dome Fuji, Antarctica, Sci. Dril., 5, 41-43, https://doi.org/10.2204/iodp.sd.5.05.2007, 2007.

Nicolas, J. P. and Bromwich, D. H.: Climate of West Antarctica and Influence of Marine Air Intrusions, J. Climate, 24, 49-67, https://doi.org/10.1175/2010JCLI3522.1, 2011.

Nigro, M. A., Cassano, J. J., and Seefeldt, M. W.: A weather pattern-based approach to evaluate the Antarctic Mesoscale Prediction System (AMPS) forecasts: Comparison to automatic weather station observations, Weather Forecast., 26, 184-198, https://doi.org/10.1175/2010WAF2222444.1, 2011.

Nigro, M. A., Cassano, J. J., and Knuth, S. L.: Evaluation of Antarctic Mesoscale Prediction System (AMPS) cyclone forecasts using infrared satellite imagery, Antarct. Sci., 24, 183-192, https://doi.org/10.1017/S0954102011000745, 2012.

Noone, D., Turner, J., and Mulvaney, R.: Atmospheric signals and characteristics of accumulation in Dronning Maud Land, Antarctica, J. Geophysic. Res., 104, 19191-19211, 1999.

Powers, J. G.: Numerical prediction of an Antarctic severe wind event with the Weather Research and Forecasting (WRF) Model, Mon. Weather Rev., 135, 3134-3157, 2007.

Powers, J. G., Monaghan, A. J., Cayette, A. M., Bromwich, D. H., Kuo, Y., and Manning, K. W.: Real-time mesoscale modeling over Antarctica. The Antarctic Mesoscale Prediction System, B. Am. Meteorol. Soc., 84, 1522-1545, 2003.

Powers, J. G., Manning, K. W., Bromwich, D. H., Cassano, J. J., and Cayette, A. M.: A decade of Antarctic science support through AMPS, B. Am. Meteorol. Soc., 93, 1699-1712, 2012.

Raphael, M., Marshall, G. J., Turner, J., Fogt, R. L., Schneider, D., Dixon, D. A., Hosking, J. S., Jones, J. M., and Hobbs, W. R.: The Amundsen Sea Low. Variability, change, and Impact on Antarctic Climate, B. Am. Meteorol. Soc., 29, 111-121, https://doi.org/10.1175/BAMS/D-14-00018.1, 2016.

Reijmer, C. H. and van den Broeke, M. R.: Temporal and spatial variability of the surface mass balance in Dronning Maud Land, Antarctica, J. Glaciol., 49, 512-520, 2003.

Ritter, F., Steen-Larsen, H. C., Werner, M., Masson-Delmotte, V., Orsi, A., Behrens, M., Birnbaum, G., Freitag, J., Risi, C., and Kipfstuhl, S.: Isotopic exchange on the diurnal scale between near-surface snow and lower atmospheric water vapor at Kohnen station, East Antarctica, The Cryosphere, 10, 16471663, https://doi.org/10.5194/tc-10-1647-2016, 2016. 
Scarchilli, C., Frezzotti, M., and Ruti, P. M.: Snow precipitation at for ice core sites in East Antarctica: Provenance, seasonality and blocking factors, Clim. Dynam., 37, 2107-2125, https://doi.org/10.1007/s00382-010-0946-4, 2011.

Schlosser, E., Reijmer, C. H., Oerter, H., and Graf, W.: The influence of precipitation origin on the $\delta^{18} \mathrm{O}-\mathrm{T}$ relationship at Neumayer Station, Ekströmisen, Antarctica, Ann. Glaciol., 39, 4148, 2004.

Schlosser, E., Duda, M. G., Powers, J. G., and Manning, K. W.: The precipitation regime of Dronning Maud Land, Antarctica, derived from AMPS (Antarctic Mesoscale Prediction System) Archive Data, J. Geophys. Res., 113, D24108, https://doi.org/10.1029/2008JD009968, 2008.

Schlosser, E., Manning, K. W., Powers, J. G., Duda, M. G., Birnbaum, G., and Fujita, K.: Characteristics of high-precipitation events in Dronning Maud Land, Antarctica, J. Geophys. Res., 115, D14107, https://doi.org/10.1029/2009JD013410, 2010a.

Schlosser, E., Powers, J. G., Duda, M. G., Manning, K. W., Reijmer, C. H., and Van den Broeke, M.: An extreme precipitation event in Dronning Maud Land, Antarctica - a case study using AMPS (Antarctic Mesoscale Prediction System) archive data, Polar Res., 29, 330-344, https://doi.org/10.1111/j.17518369.2010.00164.x, 2010b.

Schlosser, E., Anschütz, H., Divine, D., Martma, T., Sinisalo, A., Altnau, S., and Isaksson, E.: Recent climate tendencies on an East Antarctic ice shelf inferred from a shallow firn core network, J. Geophys. Res., 119, 6549-6562, https://doi.org/10.1002/2013JD020818, 2014.

Schlosser, E., Stenni, B., Valt, M., Cagnati, A., Powers, J. G., Manning, K. W., Raphael, M., and Duda, M. G.: Precipitation and synoptic regime in two extreme years 2009 and 2010 at Dome C, Antarctica - implications for ice core interpretation, Atmos. Chem. Phys., 16, 4757-4770, https://doi.org/10.5194/acp16-4757-2016, 2016.

Schoenemann, S. W. and Steig, E. J.: Seasonal and spatial variations of ${ }^{17} \mathrm{O}$ excess and dexcess in Antarctic precipitation: Insights from an intermediate complexity isotope model, J. Geophys. Res.-Atmos., 121, 11215-11247, https://doi.org/10.1002/2016JD025117, 2016.

Schoenemann, S. W., Steig, E. J., Ding, Q., Markle, B. R., and Schauer, A. J.: Triple water-isotopologue record from WAIS Divide, Antarctica: Controls on glacial-interglacial changes in ${ }^{17} \mathrm{O}$ excess of precipitation, J. Geophys. Res.-Atmos., 119, 87418763, https://doi.org/10.1002/2014JD021770, 2014.

Seefeldt, M. W. and Cassano, J. J.: An analysis of low-level jets in the greater Ross Ice Shelf region based on numerical simulations, Mon. Weather Rev., 136, 4188-4205, https://doi.org/10.1175/2007JAMC1442.1, 2008.

Seefeldt, M. W. and Cassano, J. J.: A description of the Ross Ice Shelf air stream (RAS) through the use of selforganizing maps (SOMs), J. Geophys. Res., 117, D09112, https://doi.org/10.1029/2011JD016857, 2012.

Sime, L. C., Marshall, G. J., Mulvaney, R., and Thomas, E. R.: Interpreting temperature information from ice cores along the Antarctic Peninsula: ERA40 analysis, Geophys. Res. Lett., 36, L18801, https://doi.org/10.1029/2009GL038982, 2009.

Steen-Larsen, H. C., Johnsen, S. J., Masson-Delmotte, V., Stenni, B., Risi, C., Sodemann, H., Balslev-Clausen, D., Blunier, T., Dahl-Jensen, D., Ellehøj, M. D., Falourd, S., Grindsted, A.,
Gkinis, V., Jouzel, J., Popp, T., Sheldon, S., Simonsen, S. B., Sjolte, J., Steffensen, J. P., Sperlich, P., Sveinbjörnsdóttir, A. E., Vinther, B. M., and White, J. W. C.: Continuous monitoring of summer surface water vapor isotopic composition above the Greenland Ice Sheet, Atmos. Chem. Phys., 13, 4815-4828, https://doi.org/10.5194/acp-13-4815-2013, 2013.

Steen-Larsen, H. C., Sveinbjörnsdottir, A. E., Peters, A. J., MassonDelmotte, V., Guishard, M. P., Hsiao, G., Jouzel, J., Noone, D., Warren, J. K., and White, J. W. C.: Climatic controls on water vapor deuterium excess in the marine boundary layer of the North Atlantic based on 500 days of in situ, continuous measurements, Atmos. Chem. Phys., 14, 7741-7756, https://doi.org/10.5194/acp-14-7741-2014, 2014.

Steen-Larsen, H. C., Risi, C., Werner, M., Yoshimura, K., and Masson-Delmotte, V.: Evaluating the skills of isotope-enabled general circulation models against in situ atmospheric water vapor isotope observations. J. Geophys. Res.-Atmos., 122, 246263, https://doi.org/10.1002/2016JD025443, 2017.

Stenni, B., Masson-Delmotte, V., Johnsen, S., Jouzel, J., Longinelli, A., Monnin, E., Roethlisberger, R., and Selmo, E.: An Oceanic Cold Reversal During the Last Deglaciation, Science, 293, 2074 2077, 2001.

Stenni, B., Masson-Delmotte, V., Selmo, E., Oerter, H., Meyer, H., Roethlisberger, R., Jouzel, J., Cattani, O., Falourd, S., Fischer, H., Hoffmann, G., Iacumin, P., Johnsen, S. F., Minster, B., and Udisti, R.: The deuterium excess records of EPICA Dome $\mathrm{C}$ and Dronning Maud Land ice cores (East Antarctica), Quaternary Sci. Rev., 29, 146-159, 2010.

Stenni, B., Scarchilli, C., Masson-Delmotte, V., Schlosser, E., Ciardini, V., Dreossi, G., Grigioni, P., Bonazza, M., Cagnati, A., Karlicek, D., Risi, C., Udisti, R., and Valt, M.: Threeyear monitoring of stable isotopes of precipitation at Concordia Station, East Antarctica, The Cryosphere, 10, 2415-2428, https://doi.org/10.5194/tc-10-2415-2016, 2016.

Stoelinga, M. T.: A users guide to RIP Version 4.5: A program for visualizing mesoscale model output. NCAR online document, University of Washington, available at: http://www2.mmm.ucar. edu/wrf/users/docs/ripug.htm (last access: 17 October 2017), 2009.

Touzeau, A., Landais, A., Stenni, B., Uemura, R., Fukui, K., Fujita, S., Guilbaud, S., Ekaykin, A., Casado, M., Barkan, E., Luz, B., Magand, O., Teste, G., Le Meur, E., Baroni, M., Savarino, J., Bourgeois, I., and Risi, C.: Acquisition of isotopic composition for surface snow in East Antarctica and the links to climatic parameters, The Cryosphere, 10, 837-852, https://doi.org/10.5194/tc-10-837-2016, 2016.

Uemura, R., Matsui, Y., Yoshimura, K., Motoyama, H., and Yoshida, N.: Evidence of deuterium excess in water vapor as an indicator of ocean surface conditions, J. Geophys. Res., 113, D19114, https://doi.org/10.1029/2008JD010209, 2008.

Uemura, R., Masson-Delmotte, V., Jouzel, J., Landais, A., Motoyama, H., and Stenni, B.: Ranges of moisture-source temperature estimated from Antarctic ice cores stable isotope records over glacial-interglacial cycles, Clim. Past, 8, 11091125, https://doi.org/10.5194/cp-8-1109-2012, 2012.

Wendler, G. and Kodama, Y.: On the climate of Dome C, Antarctica, in relation to its geographical setting, Int. J. Climatol., 4, 495508, https://doi.org/10.1002/joc.3370040505, 1984. 